\title{
SDC2 wt Allele
}

National Cancer Institute

\section{Source}

National Cancer Institute. SDC2 wt Allele. NCI Thesaurus. Code C104999.

Human SDC2 wild-type allele is located within 8q22-q23 and is approximately $118 \mathrm{~kb}$ in

length. This allele, which encodes syndecan-2 protein, plays a role in cell-matrix interactions, cell migration, and cell proliferation. 